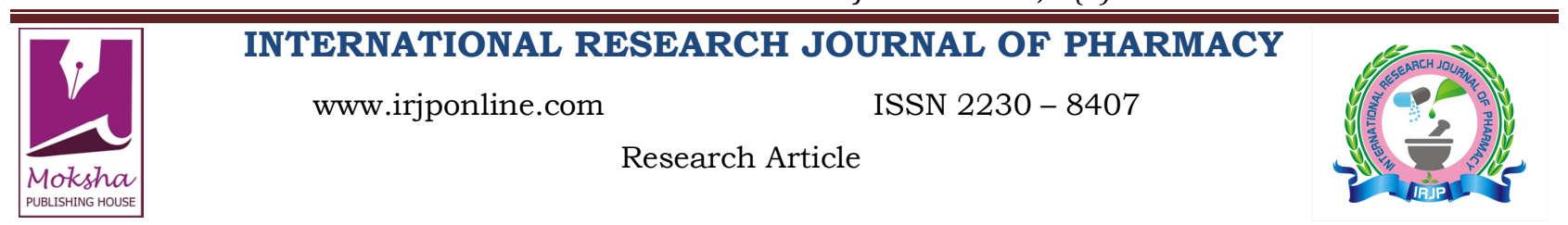

\title{
INVESTIGATION ON THE ANTI-GENOTOXIC EFFECT OF OCIMUM SANCTUM IN FLUORIDE INDUCED GENOTOXICITY
}

Kambam Srilatha ${ }^{1 *}$, David Banji ${ }^{1}$, Otilia J.F. Banji ${ }^{1}$, Vinod $\mathrm{KR}^{2}$, Abbagoni Saidulu ${ }^{1}$

${ }^{1}$ Department of Pharmacology, Nalanda College of Pharmacy, Cherlapally, Nalgonda, A.P., India

${ }^{2}$ Department of Pharmaceutics, Nalanda College of Pharmacy, Cherlapally, Nalgonda, A.P., India

Email: srilatha53@gmail.com

Article Received on: 13/03/13 Revised on: 21/04/13 Approved for publication: 11/05/13

DOI: 10.7897/2230-8407.04533

IRJP is an official publication of Moksha Publishing House. Website: www.mokshaph.com

(C) All rights reserved.

\section{ABSTRACT}

The present study was designed to investigate the anti-genotoxic effect of Ocimum sanctum on fluoride induced genotoxicity and its impact on oxidative stress. Exposure to fluoride can mainly occur through drinking water when the levels far exceed the permissible limit. Fluorosis is a serious problem the world over resulting in damage to DNA. Micronuclei assessment from bone marrow and peripheral blood was used in the present study to assess the damage to DNA. Sodium fluoride in a single dose $(30 \mathrm{mg} / \mathrm{kg}$, i.p.) was used to induce micronuclei in albino mice. Treatment with the aqueous extract of Ocimum sanctum was initiated in the single dose study $(100,400 \& 800 \mathrm{mg} / \mathrm{kg})$ and as a time course for 1 day, 3 days and 7 days $(100 \mathrm{mg} / \mathrm{kg}) .24 \mathrm{~h} \mathrm{after} \mathrm{injecting}$ sodium fluoride, the animals were sacrificed and micronuclei were determined from smears prepared from bone marrow and peripheral blood. The antioxidant impact of the extract was determined using ferric ion reducing capacity of plasma and thiobarbituric acid reactive substances as a measure of lipid peroxidation. All doses were capable of preventing the formation of micronuclei but $100 \mathrm{mg} / \mathrm{kg}$ of the aqueous extract was most efficacious as a single dose and in the time course study. The beneficial effect of Ocimum sanctum is possibly due to the synergistic action of constituents like polyphenols, triterpenoids, and flavonoids.

Key words: Fluoride, Ocimum sanctum, Micronuclei.

\section{INTRODUCTION}

Fluoride (F) is the thirteenth most abundant element $(0.065 \%$ by weight) in the earth's crust and is widely distributed in our environment ${ }^{1}$. F has been used along with calcium to stimulate osteoblasts and has therefore found a place in the treatment of osteoporosis. Fluoridation of water was found to decrease the prevalence of dental caries. Long term exposure to $\mathrm{F}$ has been reported to induce mottling of teeth, skeletal fluorosis, birth defects and cancer ${ }^{2}$. In certain areas around the world, the level of $\mathrm{F}$ in ground water might surpass the permissible limit of $1.0 \mathrm{mg} / \mathrm{L}^{3}$ creating distress to osseous tissue, liver, kidney and brain ${ }^{4}$. Nalgonda, a district in Andhra Pradesh in India is deeply afflicted with fluoride related diseases. The fluoride levels in this district range from 2 to 7 $\mathrm{mg} / \mathrm{L}$ in ground water ${ }^{3}$. Very large number of people is affected with fluorosis in this district alone.

DNA damage is one of the important consequences of exposure to some genotoxic agents ${ }^{4,5}$. Stability of the genome relies heavily on an efficient DNA repair mechanism. DNA repair can be elicited through enzymatic processes which require a few hours or non enzymatic modalities which take only a few seconds. If the DNA repair mechanisms fail to operate efficiently, then nuclear material and cellular components are susceptible to damage by oxidative stress. Exposure to mutagens and genotoxic agents can cause anomalies in the nuclear material characterized by micronuclei (MN) and disruption of chromosomal structure. Micronuclei are small spherical chromatin elements which lie outside the nucleus in a cell or in erythrocytes. They appear identical in structure, shape and size to the main nucleus in a cell.

Previous studies indicate that fluoride induces chromosome aberrations, induction of sister chromatid exchange (SCE) and DNA damage ${ }^{6}$. Damage caused by fluoride intoxication is predominantly mediated through lipid peroxidation ${ }^{4,5}$. Very few treatment strategies are available to combat the effects of fluoride.
Ocimum sanctum (family- Labiatae), commonly known as Sacred basil, is a fragrant bushy plant containing volatile oil comprising of $70 \%$ eugenol, methyl eugenol and caryophyllene. Triterpenoids like ursolic acid, rosmarinic acid, alkaloids, saponins, flavonoids, phenylpropane glucosides and tannins exist in this plant ${ }^{7,8}$. Ocimum sanctum have a plethora of reported effects which include growth promoting, anti-hypertensive, cardiac depressant, smooth muscle relaxant, antistress, hepatoprotective, anticancer, antiinflammatory, analgesic and radio protective properties ${ }^{8,9}$.

It has been reported from several studies that Ocimum sanctum is capable of protecting DNA from damage when exposed to xenobiotics like cyclophosphamide, cyproterone acetate $^{10}$ and heavy metals like $\mathrm{Cr}$ and $\mathrm{Hg}^{11}$. However no study was undertaken to ascertain the impact of Ocimum sanctum on fluoride induced genotoxicity. Ocimum sanctum is widely accessible, easily recognized medicinal herb and is found in every household. If it is found effective in reducing the deleterious effect of fluoride, it can be a boon to the population in this area. Keeping this in mind the present investigation was undertaken to evaluate the effect of aqueous extract of Ocimum sanctum on fluoride induced genotoxicity and oxidative stress in experimental animals.

\section{MATERIALS AND METHODS}

Drugs and chemicals

Sodium fluoride (Batch No.D024290179) was purchased from Universal Laboratories Pvt. Ltd, Mumbai. Bovine albumin serum and MayGrunwald-stain were purchased from Rolex Chemical Industries, Mumbai. Giemsa stain was purchased from Thermo Fischer Scientific India Pvt Ltd, Mumbai. Thiobarbituric acid was purchased from LOBA Chemie Pvt Ltd, Mumbai. All other reagents and chemicals used were of analytical grade. 


\section{Animals}

Healthy albino mice weighing 25-30 g were procured from National Institute of Nutrition, Hyderabad and acclimatized in our own animal house for one week prior to the experiment. The animals were maintained at $22 \pm 3{ }^{0} \mathrm{C}$ under natural light dark conditions and fed on standard diet with free access to deflourinated water (RO water). This experimental protocol has been approved by the institutional animal ethical committee and the experiments have been conducted as per guidelines laid down by Committee for the Purpose and Control of Supervision of Experiments on Animals (CPCSEA), Chennai, India.

\section{Plant Material}

Leaves of $O$. sanctum were collected from the local areas of Nalgonda district, Andhrapradesh, India, and were authenticated by Professor A. Laxma Reddy, Department of Botany, Nagarjuna Government Degree College, Nalgonda. A voucher specimen (No. 005) has been deposited in our herbarium.

\section{Preparation of Ocimum sanctum leaf extract}

The leaves were dried at room temperature and powdered. The aqueous extract of Ocimum sanctum (AEOS) was obtained by refluxing the powder with distilled water. $75 \mathrm{~g}$ of powder is refluxed with $500 \mathrm{ml}$ distilled water for $6 \mathrm{~h}$ at 60 ${ }^{\circ} \mathrm{C}$. The extract obtained was filtered, concentrated (yield, $10 \% \mathrm{w} / \mathrm{w}$ ) and stored in refrigerator for further use.

\section{Dose selection}

It has been reported that Ocimum sanctum is safe up to a dose of $4 \mathrm{~g} / \mathrm{kg}^{10} .100,400$ and $800 \mathrm{mg} / \mathrm{kg}$ of aqueous extract were selected for the study based on maximum tolerated dose of Ocimum sanctum. The dose of sodium fluoride selected was $30 \mathrm{mg} / \mathrm{kg}^{12}$.

\section{Experimental design}

The animals were divided into 7 groups of 6 mice each for the dose dependent and time dependent studies for peripheral and bone marrow micronucleus assay.

\section{Dose dependent study}

Group I: Animals were administered with $0.2 \mathrm{ml}$ of $1 \% \mathrm{w} / \mathrm{v}$ acacia by oral route.

Group II: Animals were administered with in a single dose of $30 \mathrm{mg} / \mathrm{kg}$ of sodium fluoride by the i.p. route to induce micronuclei.

Group III: Animals were treated with $100 \mathrm{mg} / \mathrm{kg}$ of AEOS, after $1 \mathrm{~h}$ they were injected with sodium fluoride by the i.p. route.

Group IV: Animals were treated with $400 \mathrm{mg} / \mathrm{kg}$ of AEOS, after $1 \mathrm{~h}$ they were injected with sodium fluoride by the i.p. route.

Group V: Animals were treated with $800 \mathrm{mg} / \mathrm{kg}$ of AEOS, after $1 \mathrm{~h}$ they were injected with sodium fluoride by the i.p route.

\section{Time dependent study}

Group VI: Animals were treated with $100 \mathrm{mg} / \mathrm{kg}$ of AEOS once daily for 3 days, $1 \mathrm{~h}$ after the last dose, sodium fluoride was injected i.p.

Group VII: Animals were treated with $100 \mathrm{mg} / \mathrm{kg}$ of AEOS once daily for 7 days, $1 \mathrm{~h}$ after the last dose, sodium fluoride was injected i.p.
The aqueous extract was suspended in $1 \% \mathrm{w} / \mathrm{v}$ acacia and administered to animals by oral route. Blood was withdrawn from same animals for estimation of oxidative parameters before sacrificing the animals.

\section{Peripheral blood micronucleus assay}

Peripheral blood was collected by retro orbital puncture under enflurane anesthesia in test tubes containing $1 \% \mathrm{w} / \mathrm{v}$ EDTA as an anticoagulant. Smear was prepared on slides, air dried, fixed with absolute methanol for $10 \mathrm{~min}$ and stained with phosphate buffer diluted Giemsa (1:4) for $12 \mathrm{~min}$. Slides were observed under microscope for the presence of micronuclei ${ }^{13}$.

\section{Determination of antioxidant activity by ferric reducing ability of plasma (FRAP) assay}

Plasma antioxidant status was evaluated using ferric reducing antioxidant power (FRAP) assay. The assay was carried out according to F.F.Benzie and J.J.Strain (1996). $100 \mu \mathrm{l}$ of plasma was mixed with $3 \mathrm{ml}$ of working FRAP reagent and absorbance was measured at 0 min after vortexing at $593 \mathrm{~nm}$. Thereafter, samples are placed at $37{ }^{\circ} \mathrm{C}$ in water bath and absorbance was again measured after 4 min. Ascorbic acid standards $(100 \mu \mathrm{M}-1000 \mu \mathrm{M})$ were processed in the same way $^{14}$.

\section{Estimation of Thiobarbituric acid Reactive Substances (TBARS) in plasma}

The thiobarbituric acid reactive substances levels were estimated as per the spectrophotometric method described by Ohkawa et al. $0.5 \mathrm{ml}$ of plasma was mixed with $0.5 \mathrm{ml}$ of normal saline, $1 \mathrm{ml}$ of $20 \% \mathrm{w} / \mathrm{v}$ trichloroacetic acid (TCA) and $0.67 \% \mathrm{w} / \mathrm{v}$ TBA reagent. The samples were kept for boiling at $95{ }^{\circ} \mathrm{C}$ for $1 \mathrm{~h}$. To each of the sample, $3 \mathrm{ml}$ of $\mathrm{n}$ butanol was added, mixed well and centrifuged at $3000 \mathrm{rpm}$ for $10 \mathrm{~min}$. The separated butanol layer was collected and read in a spectrophotometer against reagent blank at $535 \mathrm{~nm}$. TBARS concentration was expressed in terms of $\mu \mathrm{mol}$ of malondialdehyde per milliliter of plasma ${ }^{15}$.

\section{Bone marrow micronucleus assay}

The same experimental animals were used for both peripheral blood $\mathrm{MN}$ and bone marrow MN assays. Animals in all groups were sacrificed by cervical dislocation $24 \mathrm{~h}$ after the intraperitoneal injection of sodium fluoride. Animals were dissected to excise femur. Marrow suspension from femur bone was prepared in 5\% bovine serum albumin (BSA) and centrifuged at $1000 \mathrm{rpm}$. The pellet formed was resuspended in a required quantity of BSA. A drop of this suspension was taken on clean glass slides, smears were prepared and the slides were air-dried. The slides were fixed in methanol, stained with May-Gruenwald-Giemsa and MN were identified in two forms of red blood cells which are Polychromatic Erythrocytes as PCE and Normochromatic Erythrocytes as NCE using binocular microscope under oil immersion objective. About 500 PCE and corresponding NCE per animal were observed for the presence of $\mathrm{MN}^{13}$.

\section{Statistical analysis}

Data are expressed as mean \pm SEM. Analysis of data was done by One-way ANOVA followed by Dunnett comparison test for FRAP and TBARS. Mann-Whitney U test was carried out for micronuclei in bone marrow and peripheral blood using Graph Pad In Stat version 3.10 for 
Windows 2009 (Graph Pad Software). The statistical significance was set as 0.01 and $0.05(\mathrm{P}<0.01, \mathrm{P}<0.05)$.

Table 1: Effect of aqueous extract of Ocimum sanctum on the frequency of micronuclei in bone marrow and peripheral blood induced by sodium fluoride

\begin{tabular}{|c|c|c|c|c|}
\hline \multirow[t]{2}{*}{ S.NO } & \multirow[t]{2}{*}{ Treatment } & \multicolumn{2}{|c|}{ Bone marrow micronucleus test } & Peripheral blood micronucleus test \\
\hline & & $\% \mathrm{MNPCE}^{\mathrm{a}}$ & $\% \mathrm{MNNCE}^{\mathrm{b}}$ & $\% \mathrm{MNNCE}^{\mathrm{c}}$ \\
\hline 1 & Negative control & $0.4 \pm 0.12$ & $0.2267 \pm 0.08$ & $0 \pm 0.00$ \\
\hline 2 & $\mathrm{SF}(30 \mathrm{mg} / \mathrm{kg})$ & $9.2 \pm 0.42$ & $0.993 \pm 0.09$ & $3 \pm 0.26$ \\
\hline 3 & AEOS $(100 \mathrm{mg} / \mathrm{kg})$ & $1.4 \pm 0.05^{* *}$ & $0.2698 \pm 0.07^{* *}$ & $0.233 \pm 0.06^{* *}$ \\
\hline 4 & AEOS (400 mg/kg) & $1.83 \pm 0.21^{* *}$ & $0.3675 \pm 0.10^{* *}$ & $0.266 \pm 0.04^{* *}$ \\
\hline 5 & AEOS $(800 \mathrm{mg} / \mathrm{kg})$ & $3.4 \pm 0.36^{* *}$ & $0.5617 \pm 0.14^{*}$ & $0.33 \pm 0.04^{* *}$ \\
\hline 6 & AEOS $(100 \mathrm{mg} / \mathrm{kg})$ for 3 days & $0.933 \pm 0.12^{* *}$ & $0.142 \pm 0.05^{* *}$ & $0.133 \pm 0.04^{* *}$ \\
\hline 7 & AEOS $(100 \mathrm{mg} / \mathrm{kg})$ for 7 days & $0.4 \pm 0.15^{* *}$ & $0.000 \pm 0.0$ & $0.066 \pm 0.04^{* *}$ \\
\hline
\end{tabular}

Values are expressed as Mean \pm SEM, $\mathrm{n}=6$, Statistics: Mann-Whitney U test, ${ }^{* *} \mathrm{P}<0.01, * \mathrm{P}<0.05$ compared with positive control,

a) from $3000 \mathrm{PCE}$ and b) corresponding NCE counted. c) from $3000 \mathrm{NCE}$. MNPCE: micronucleated polychromatic erythrocytes, MNNCE: Micro nucleated normochromatic erythrocytes, SF: Sodium fluoride, AEOS: aqueous extract of Ocimum sanctum

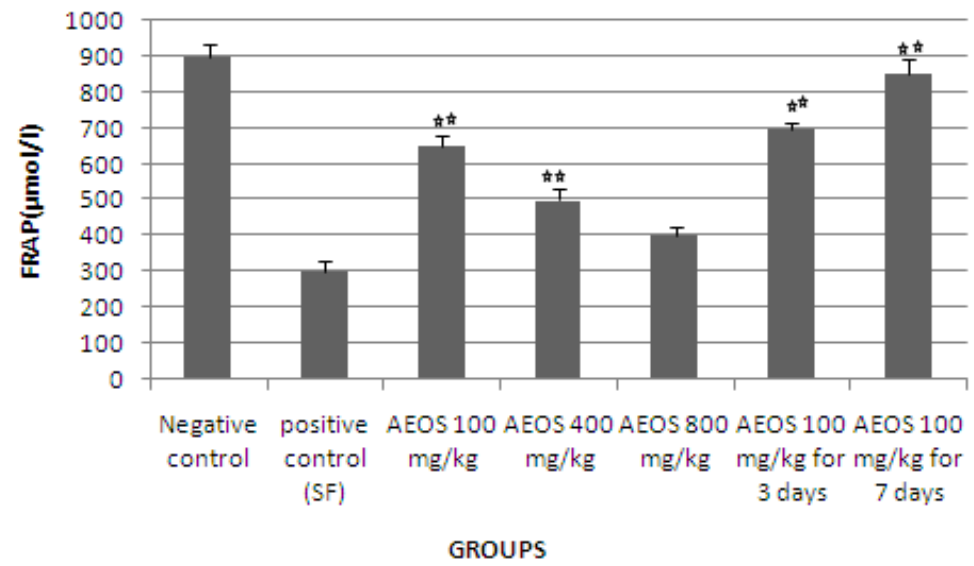

Figure 1: Effect of aqueous extract of $O$.sanctum on plasma antioxidant capacity in fluoride induced genotoxicity. Values are Mean \pm SEM, $n=6$, $* * \mathbf{P}<0.01$ compared with positive control. AEOS: aqueous extract of Ocimum sanctum, SF: sodium fluoride.

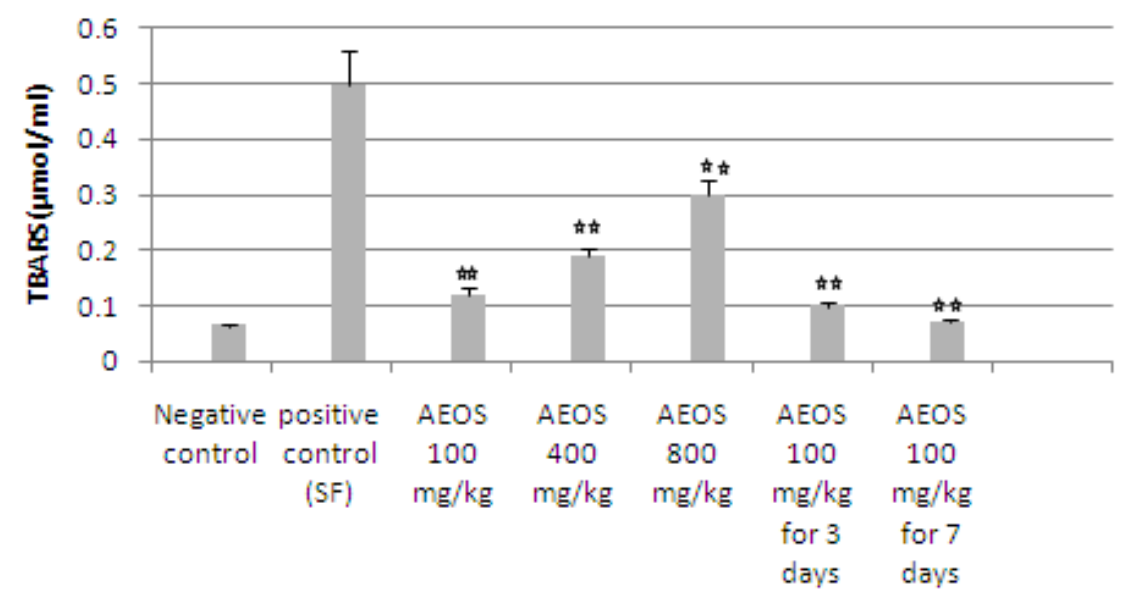

GROUPS

Figure 2: Effect of aqueous extract of $O$.sanctum on concentration of TBARS in fluoride induced genotoxicity. Values are expressed as Mean \pm SEM, $\mathrm{n}=6, \quad * * \mathbf{P}<0.01$ compared with positive control. AEOS: aqueous extract of Ocimum sanctum, SF: sodium fluoride. 

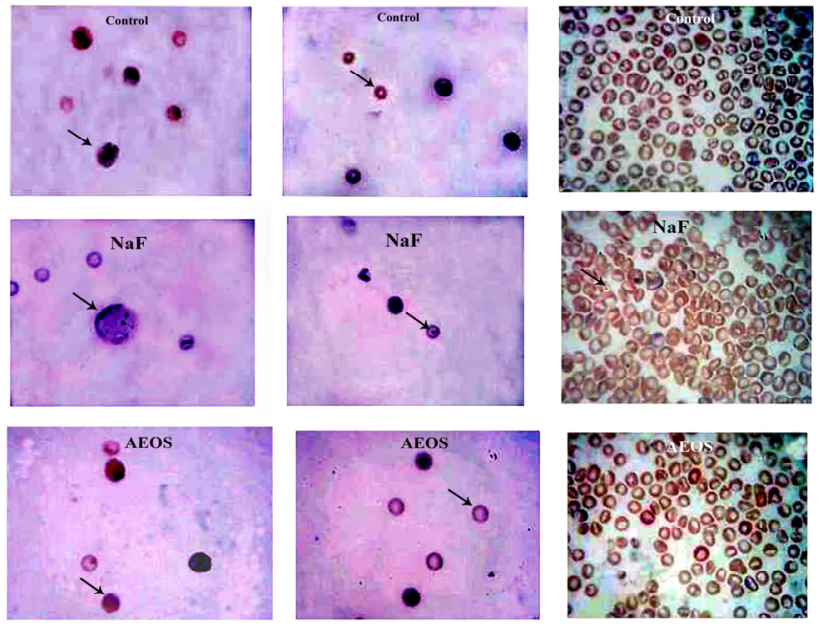

Figure 3: Photographs showing micro nucleated erythrocytes in bone marrow and peripheral blood. Control and MNPCE and MNNCE in bone marrow in sodium fluoride treated group. AEOS treatment $100 \mathrm{mg} / \mathrm{kg}$ and AEOS $100 \mathrm{mg} / \mathrm{kg}$ for 7 days in bone marrow and peripheral blood respectively.

\section{RESULTS}

\section{Peripheral blood micronucleus assay}

A single intraperitoneal exposure with sodium fluoride $(30$ $\mathrm{mg} / \mathrm{kg}$ ) was capable of inducing MN (MNNCE) within $24 \mathrm{~h}$. Treatment with a dose of $100 \mathrm{mg} / \mathrm{kg}$ of AEOS exerted a significant reduction in the formation of MNNCE induced by $\mathrm{F}$ indicating that low dose of AEOS is more effective in prevention of $\mathrm{MN}$. The number of MNNCE observed with 400 and $800 \mathrm{mg} / \mathrm{kg}$ of AEOS also declined but the effect was less pronounced than that produced by $100 \mathrm{mg} / \mathrm{kg}$ AEOS (Table I). In time course studies, treatment with a dose of 100 $\mathrm{mg} / \mathrm{kg}$ of AEOS for 7 days exerted a significant reduction in the formation of MNNCE induced by F compared with the positive control (Table 1).

Determination of antioxidant activity by ferric reducing ability of plasma (FRAP) assay

The antioxidant activity of group of animals treated with 100 $\mathrm{mg} / \mathrm{kg}$ of AEOS was found to be more than group of animals treated with $400 \mathrm{mg} / \mathrm{kg}$ and $800 \mathrm{mg} / \mathrm{kg}$ of AEOS. The same dose $(100 \mathrm{mg} / \mathrm{kg})$ was found to possess better antioxidant activity when treated for 7 days (Figure 1).

\section{Estimation of Thiobarbituric acid Reactive Substances} (TBARS) in plasma

Oxidative stress represented by the concentration of TBARS was found to be less in group-3 treated with $100 \mathrm{mg} / \mathrm{kg}$ than animals treated with $400 \mathrm{mg} / \mathrm{kg}$ and $800 \mathrm{mg} / \mathrm{kg}$ of AEOS. When treatment was continued for 3 and 7 days with 100 $\mathrm{mg} / \mathrm{kg}$, a significant reduction in the formation of oxidative stress markers was observed (Figure 2).

\section{Bone marrow micronucleus assay}

In dose-dependent study, the number of MNPCE and MNNCE were reduced in groups treated with $400 \mathrm{mg} / \mathrm{kg}$ and $800 \mathrm{mg} / \mathrm{kg}$ of AEOS. The group treated with $100 \mathrm{mg} / \mathrm{kg}$ of AEOS exhibited a fair reduction in MNPCE and MNNCE formed compared with the $F$ treated group $(P<0.05)$. In the time dependent studies, the proportion of MNPCE and MNNCE formed declined as the duration of treatment with AEOS (100 mg/kg) progressed (Table 1).

\section{DISCUSSION}

Xenobiotics or chemicals can induce changes in the biological system as they would be recognized by the body as foreign substance. Damage induced by chemicals can be manifested at the cellular or molecular level resulting in organ toxicity or DNA damage. Generally, the physiological system possesses several repair mechanisms to safeguard cell, cell organelles and genetic material from damage. Recurrent exposure for prolonged periods might shift this balance resulting in evident DNA damage.

Exposure to environmental hazards like fluoride can take place mainly through drinking water ${ }^{6}$. Fluoride is a biologically active element which has a tendency to cumulate in the body as only $50 \%$ of it undergoes renal clearance ${ }^{16}$. F is known to inhibit various enzymes and this might result in its interference in DNA repair mechanism which utilizes several enzymes. $\mathrm{F}$ is regarded as a true mutagen as it is capable of forming covalent bonds with DNA inducing significant chromosomal damage ${ }^{4}$. The damage caused by $\mathrm{F}$ could be due to its ability to induce oxidative stress. Generation of reactive oxygen species due to oxidative stress occurs when molecular oxygen undergoes reduction and actively accepts single electrons converting into superoxide radicals. The generated reactive oxygen species readily attack the methylene groups of polyunsaturated fatty acids facilitating lipid peroxidation ${ }^{17}$. The end product of lipid peroxidation which is TBARS evidently rises due to oxidative stress. Insult caused by reactive oxygen species is not restricted to the cell membrane alone, but can readily extend to proteins and nucleic acids. Therefore DNA damage is evident due to oxidative stress.

DNA damage can be easily detected by cytogenetic analysis to detect the presence of micronuclei. An important biomarker of DNA damage is detection of $\mathrm{MN}$ in bone marrow and peripheral blood. The bone marrow micronucleus assay developed by Schmid relies on the fact that chromosomal fragments or entire chromosomes might fail to incorporate into the nucleus after cell division. Due to this, small chromatin containing element might appear in the cell around the nucleus which are detected as micronuclei. The erythropoeitic lineage comprises various cells during their developmental cascade of which polychromatic 
erythrocytes and normochromatic erythrocytes are the most prominent. Further nuclear damage can be assessed by counting the number of $\mathrm{MN}$. If the proportion of $\mathrm{MN}$ is more than $6 \%$, it implies that the agent is mutagenic ${ }^{18}$. Our observations reveal that genomic integrity was disturbed by the administration of sodium fluoride.

Evaluation of the total anti-oxidant capacity of AEOS revealed a significant decline in the FRAP values in $F$ challenged group compared with control. $100 \mathrm{mg} / \mathrm{kg}$ of AEOS as a single schedule and for a period of 7 days considerably increased FRAP values. Studies have shown a reduction in the formation of an important marker of oxidative stress which is TBARS following treatment with AEOS in a dose of $100 \mathrm{mg} / \mathrm{kg}$ for 7 days. AEOS in lower doses as a single schedule and in the same dose for longer duration was capable of restoring the integrity of DNA by reducing the formation of $\mathrm{MN}$ compared to the groups treated with 400 and $800 \mathrm{mg} / \mathrm{kg}$.

Ocimum sanctum is a spiritually revered and popular medicinal plant commonly called as the sacred basil. It contains volatile oils, triterpenes, flavonoids, tannins, alkaloids, phenylpropane glycosides. Analysis of the active constituents reveals the occurrence of polyphenolic compounds. Polyphenolic compounds possess one or more phenolic moieties which can readily interact with free radicals leading to their depletion. TBARS, an oxidative stress marker of lipid peroxidation is known to interact with DNA causing strand breaks leading to genomic instability. The competency of Ocimum sanctum as an anti-oxidant is undoubted based on assessments made from the FRAP and lipid peroxidation studies. Several studies have reported the protective effect of ursolic acid on irradiation induced damage of hematopoietic cells and keratinocytes ${ }^{19}$. It has also been documented that ursolic acid has potential antioxidant property. The anti-mutagenic and anti-oxidant profile of $O$. sanctum extract can be attributed to the presence of triterpenoids like ursolic acid and rosmarinic acid. Reports suggest that flavonoids present in Ocimum sanctum can protect against injury caused by radiation and noise induced oxidative stress. The presence of flavonoids like orientin and vicenin might also contribute to the beneficial effects of $O$. sanctum against $\mathrm{F}$ induced genotoxicity ${ }^{20}$. Ocimum sanctum contains polyphenols which could exert its antioxidant action by preventing formation of oxidative stress markers or facilitating the detoxification of $\mathrm{F}$ or complexing with iron and copper which are minerals functioning as catalyst in free radical generation reactions ${ }^{21}$. Appraisal of lipid peroxidation, bone marrow and peripheral blood micronuclei studies clearly show that AEOS is more effective at a dose of $100 \mathrm{mg} / \mathrm{kg}$ in the dose dependent schedule and at the same dose when treated for 7 days. It was difficult to discern the reason for the slight decrease in protection with increase in the dose of the extract. However, we suggest that this might occur due to a complex interaction of several constituents present in $O$. sanctum such as alkaloids, as alkaloids are reported to possess mutagenic properties ${ }^{22}$.

In conclusion it can be stated that $O$. sanctum possesses antigenotoxic effect by circumventing $\mathrm{F}$ induced oxidative stress and DNA damage.

\section{REFERENCES}

1. Li Y, Dunipace AJ, Stookey GK. Lack of genotoxic effects of fluoride in the mouse bone-marrow micronucleus test. J Dent Res 1987; 66: 1687-1690. http://dx.doi.org/10.1177/00220345870660111701
2. Kaminsky LS, Mahoney MC, James Leach, James Melius, Mary Miller Jo. Fluoride: Benefits and Risks of Exposure. Oral Biology and Medicine 1990; 1: 261-281.

3. Narayana AS, Khandare AL, Krishnamurthi MVRS. Mitigation of fluorosis in Nalgonda district villages. 4th International Workshop on Fluorosis Prevention and Defluoridation of Water. 98-106.

4. Wang Ai-guo, Tao Xia, Long chu Qi et al. Effects of fluoride on lipid peroxidation, DNA damage and apoptosis in human embryo hepatocytes. Biomedical and environmental sciences 2004; 17: 217-222.

5. Ming Zhang, Aiguo Wang, Tao Xia, Ping He. Effects of fluoride on DNA damage, S-phase cell-cycle arrest and the expression of NF-KB primary cultured rat hippocampal neurons. Toxicology Letters 2008; 179: 1-5. http://dx.doi.org/10.1016/j.toxlet.2008.03.002

6. Santosh P, Chattopadhyay A, Bhattacharya S, Ranjan Ray M, Birbhum. Differential invivo genotoxic effects of lower and higher concentrations of fluoride in mouse bone marrow cells. Fluoride 2008; 41: 301-307.

7. Geetha, Kedlaya R, Vasudevan DM. Inhibition of lipid peroxidation by botanical extracts of Ocimum sanctum: In vivo and in vitro studies. Life Sci 2004; 76: 21-28. http://dx.doi.org/10.1016/j.lfs.2004.05.036

8. Adhvaryu MR, Srivastav SP, Vaniawala SN, Reddy MN.A comparative study of radioprotection by four Indian medicinal herbs sub-lethal gamma irradiation in swiss albino mice. Iran J Radiat Res 2008; 6: 1930 .

9. Somashekar Shetty, Saraswati Udupa, Laxminarayana Udupa. Evaluation of Antioxidant and Wound Healing Effects of Alcoholic and Aqueous Extract of Ocimum sanctum Linn in Rats. eCAM 2007; 1-7.

10. Siddique YH, Gulshan Ara, Beg T, Afzal M. Anti-genotoxic effect of ocimum sanctum L. extract against cyproterone acetate induced genotoxic damage in cultured mammalian cells. Acta Biologica Hungarica 2007; 58: 397-409. http://dx.doi.org/10.1556/ABiol. 58.2007.4.7

11. Babu K, Uma Maheswari KC. In vivo studies on the effect of Ocimum sanctum L. leaf extract in modifying the genotoxicity induced by chromium and mercury in allium root meristems. Journal of Environmental Biology 2006; 27: 93-95.

12. Suzuki Y, Li J, Shimizu H. Induction of micronuclei by sodium fluoride. Mutation Research 1991; 253:278. http://dx.doi.org/10.1016/01651161(91)90221-S

13. Seetharamarao KP, Narayana K. Invivo chromosome damaging effects of an inosine monophosphate dehydrogenase inhibitor: Ribavirin in mice. Indian J Pharmacol 2005; 37: 90-95. http://dx.doi.org/10.4103/ 0253-7613.15108

14. Benzie FF, Strain JJ. The ferric reducing ability of plasma (FRAP) as a measure of "Antioxidant Power": The FRAP Assay. Analytical biochemistry 1996; 239: 70-76. http://dx.doi.org/10.1006/ abio. 1996.0292

15. Premanand R, Santhosh Kumar PH, Alladi Mohan. Study of thiobarbituric reactive Substances and total reduced glutathione as indices of oxidative stress in chronic smokers with and without chronic obstructive pulmonary disease. J Chest Dis Allied Sci 2007; 49: 9-12.

16. Connett P. 50 Reasons to Oppose Fluoridation. St. Lawrence University, NY 13617 315-229-5853.

17. Dariusz Chlubek. Fluoride and oxidative stress. Fluoride 2003; 36: $217-$ 228.

18. Syed imam rabbani, Kshama devi, Salma khanam, Noor Zahra. Citral, a component of lemongrass oil inhibits the clastogenic effect of nickel chloride in mouse micronucleus test system. Pak. J Pharm Sci 2006; 19: $108-113$.

19. Ramachandran S, Rajendra Prasad N. Effect of ursolic acid, a triterpenoid antioxidant on ultraviolet-B radiation-induced cytotoxicity lipid peroxidation and DNA damage in human lymphocytes. ChemicoBiological Interactions 2008; 176: 99-107. http://dx.doi.org /10.1016/j.cbi.2008.08.010

20. Joseph Weiss F, Michael Landauer R. Protection against ionizing radiation by antioxidant nutrients and phytochemicals. Toxicology 2003; 189: 1-2. http://dx.doi.org/10.1016/S0300-483X(03)00149-5

21. Lynnette Ferguson R. Role of plant polyphenols in genomic stability. Mutation Research 2001; 475: 89-111. http://dx.doi.org/10.1016/S00275107(01)00073-2

22. Santos-Mello R, Deimlimg LI, Lauer Júnior CM, Almeida A. Induction of micronuclei by alkaloids extracted from Senecio brasiliensis and stored for 23 years. Mutation Research 2002; 516: 23-28. http:// dx.doi.org/10.1016/S1383-5718(02)00008-6

Cite this article as:

Kambam Srilatha, David Banji, Otilia J.F. Banji, Vinod KR, Abbagoni Saidulu. Investigation on the anti-genotoxic effect of Ocimum sanctum in fluoride induced genotoxicity. Int. Res. J. Pharm. 2013; 4(5):160-164 